\title{
Pterygodermatites (Multipectines) affinis (Jägerskiöl, 1904) (Nematoda: Rictulariidae), a parasite of Cerdocyon thous (Linnaeus, 1766) (Carnivora: Canidae) from the Brazilian Amazon
}

\author{
Pterygodermatites (Multipectines) affinis (lägerskiöl, 1904) \\ (Nematoda: Rictulariidae), um parasito de Cerdocyon thous \\ (Linnaeus, 1766) (Carnivora: Canidae) da Amazônia brasileira \\ Naida Paola Araújo da Silva ${ }^{1,2}$ (D); Ana Rita de Lima ${ }^{3}$ (D); Érika Branco ${ }^{3}$ (D); Raul Henrique da Silva Pinheiro ${ }^{2,4}$ (D); \\ Elane Guerreiro Giese ${ }^{1,2 *}$ (D)

\footnotetext{
'Programa de Pós-graduação em Biologia de Agentes Infecciosos e Parasitários, Instituto de Ciências Biológicas, Universidade Federal do Pará - UFPA, Belém, PA, Brasil

${ }^{2}$ Laboratório de Histologia e Embriologia Animal, Instituto da Saúde e Produção Animal, Universidade Federal Rural da Amazônia UFRA, Belém, PA, Brasil

${ }^{3}$ Laboratório de Pesquisa Morfológica Animal, Instituto da Saúde e Produção Animal, Universidade Federal Rural da Amazônia - UFRA, Belém, PA, Brasil

${ }^{4}$ Programa de Pós-graduação em Sociedade, Natureza e Desenvolvimento, Instituto de Ciências e Tecnologia das Águas, Universidade Federal do Oeste do Pará - UFOPA, Santarém, PA, Brasil
}

How to cite: Silva NPA, Lima AR, Branco E, Pinheiro RHS, Giese EG. Pterygodermatites (Multipectines) affinis (Jägerskiöl, 1904) (Nematoda: Rictulariidae), a parasite of Cerdocyon thous (Linnaeus, 1766) (Carnivora: Canidae) from the Brazilian Amazon. Braz J Vet Parasitol 2020; 29(3): e003220. https://doi.org/10.1590/S1984-29612020041

\begin{abstract}
Among the Nematodes of Cerdocyon thous, the genus Pterygodermatites is characteristic for presenting cuticular projections along the body, being mentioned in different hosts in South America, although there are no records of its occurrence in the Amazon Biome. To enable further exploration in terms of their morphology and morphometry, the nematodes collected from cadavers of $C$. thous were fixed and observed using bright field microscopy and scanning electron microscopy, revealing characteristics compatible with $P$. (Multipectines) affinis, thus contributing more information about the geographic distribution of the parasite, as well as knowledge of the helminthological fauna of wild mammals in the Brazilian Amazon.
\end{abstract}

Keywords: Nematoda, wild mammal, geographic distribution, Amazon.

\section{Resumo}

Entre os nematodas de Cerdocyon thous, o gênero Pterygodermatites é característico por apresentar projeções cuticulares ao longo do corpo, sendo citado em diferentes hospedeiros na América do Sul, porém, sem registros de sua ocorrência no Bioma Amazônia. Passível de maior exploração quanto à sua morfologia e morfometria, os nematoides colhidos de cadáveres de $C$. thous foram fixados e observados em microscopia de campo claro e microscopia eletrônica de varredura, revelando características compatíveis com P. (Multipectines) affinis. Com isso contribuiu com mais informações sobre a distribuição geográfica do parasito, bem como o conhecimento da fauna helmintológica de mamíferos selvagens na Amazônia brasileira.

Palavras-chaves: Nematoda, mamífero selvagem, distribuição geográfica, Amazônia. 


\section{Introduction}

Cerdocyon thous (Linnaeus, 1766) is considered the most versatile of Brazilian canids, as it has high adaptability to different habitats and explores a large number of food items (Berta, 1982). In Brazil, among wild carnivores, C. thous is one of the species that most often dies run over (Prada, 2004).

Different authors have prepared taxonomic inventories of helminthofauna in captive and free-living wild mammals in Brazil (Vicente et al., 1997; Vieira et al., 2008; Pinto et al., 2011), although this available literature is not strictly restricted to helminths in carnivores (Vieira et al., 2008). Among mammal helminths in Brazil, nematodes are a very common group (Brandão et al., 2009).

More than one hundred years after Pinheiro et al. (2018) recorded the nematofauna of $C$. thous in the country as being composed of 24 species of nematodes. Among the parasites of Family Rictulariidae Railliet, 1916, two genera for the crab-eating fox (Rictularia Froehlich, 1802 and Pterygodermatites Wedl, 1861) were registered, the latter being divided into five Subgenera (Paucipectines, Multipectines, Pterygodermatites, Neopaucipectines and Mesopectines) according to cephalic structures, geographic distribution, hosts and number of cuticular processes (Quentin, 1969).

According to Simões (2016), although new taxonomic studies of the genre Pterygodermatites have been carried out, it is necessary to conduct a more updated survey on the group's taxonomy; after all, it has been more than 40 years since the systematic survey done by Quentin (1969). This work adds morphological and morphometric data for P. (Multipectines) affinis (Jägerskiöl, 1904), and describes for the first time the occurrence of this parasite in northern Brazil, thus expanding its geographical distribution.

\section{Materials and Methods}

We evaluated the intestine of five animals (C. thous) from the HYDRO Paragominas Bauxite Mine. These had been killed by being run over and were frozen and sent to the Laboratório de Pesquisa Morfológica Animal (LaPMA) - Universidade Federal Rural da Amazônia (UFRA), (SEMA-PA authorization No. 455/2009 and 522/2009).

The animals were thawed in running water, for a period of approximately two hours, and the access to the abdominal cavity occurred through an incision in the alba line, allowing the intestines to bounce, which were separated in plastic trays, and then fragments of the intestine were placed in plates. Petri dish with saline and examined with a stereomicroscope (LEICA ES2: Wetzlar, Germany).

The nematode found dead were fixed in AFA solution (93 parts 70\% ethyl alcohol, 5 parts formaldehyde, and 2 parts glacial acetic acid), stored at room temperature. For morphological and morphometric analysis 10 males, 10 females and 40 eggs in utero of adult females were measured. Adult nematodes were processed using light microscopy and scanning electron microscopy according to method described by Pinheiro et al. (2018). The measurements were recorded in micrometers, unless otherwise indicated and were presented as the average followed by the range (minimum and maximum values) in parentheses. The taxonomic classification of nematodes was in accordance with Anderson et al. (2009). The ecological indexes of parasitism were used according to Bush et al. (1997).

\section{Results}

A total of 81 ( 36 males and 45 females) nematodes were recovered from small intestines of the five $C$. thous showing prevalence: $100 \%$ (5 infected, 5 examined), mean intensity: 16.2, mean abundance: 16.2 and amplitude: 3 to 24 nematodes per animal. All specimens collected showed characteristics compatible with genus Pterygodermatites, and, based on the morphological examination, the specimens were identified as $P$. (Multipectines) affinis (J̈̈gerskiöl, 1904), whose morphological and morphometric characteristics are shown below and on table 01.

Rictulariidae Railliet, 1916

Pterygodermatites (Multipectines) affinis (Jägerskiöl, 1904)

(Based on light microscopy and scanning electron microscopy examination: Figure 1-2)

Medium-sized nematodes with two subventral projection rows (Figure 1a). The oral cavity was triangular, surrounded by three concentric circles of papillae distributed in: an inner circle of 4 papillae ( 1 ventral pair and 1 dorsal pair), there was a pair of amphids between the ventral and dorsal labial papillae. According to external circles, one with 6 papillae ( 1 ventral pair, 1 dorsal pair and 1 lateral pair adjacent to amphibians) and the outer circles showing four simple papillae (Figure 2a). Sexual dimorphism in the morphology of the head end is entirely 

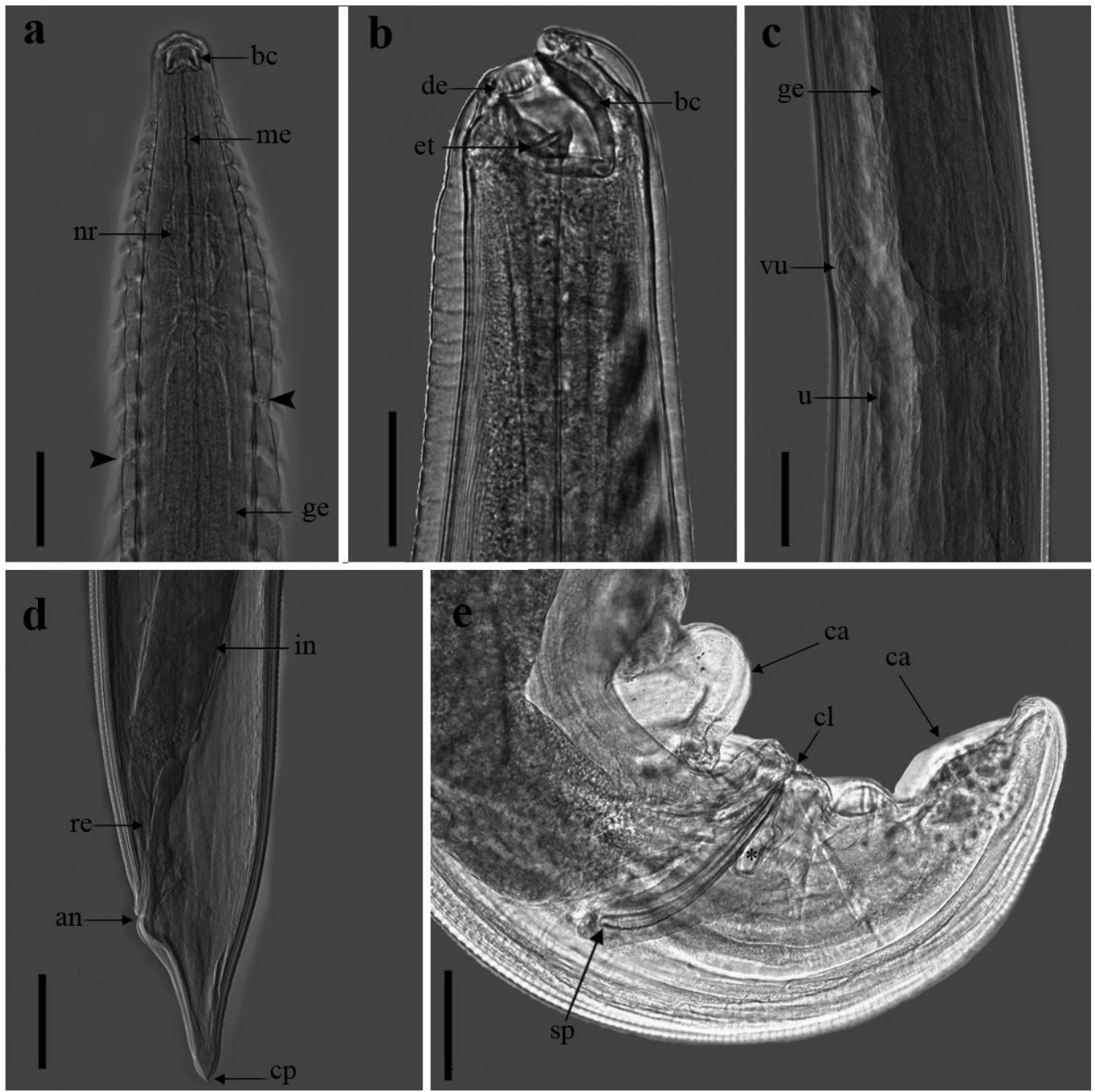

Figure 1. Light microscopy of Pterygodermatites (M.) affinis parasite of Cerdocyon thous in the state of Pará, Brazil. (a) Overview of the anterior region: buccal capsule (bc), muscular esophagus (me), nerve ring (nr), initial portion of glandular esophagus (ge) and deirids (arrowhead). Bar: $100 \mu \mathrm{m}$; (b) Detail anterior region: buccal capsule (bc) with buccal opening armed with denticles (de), esophageal tooth (et) at the base of the capsule. Bar: $50 \mu \mathrm{m}$; (c) Final portion of the glandular esophagus (ge), vulvar opening (vu) located above the esophagus-intestine junction, followed by the uterus (u). Bar: $100 \mu \mathrm{m}$; (d) Posterior end of female in lateral view: final portion of the intestine (in), rectum (re), and opening of the anus (an), digitiform cuticular projection (cp). Bar: $100 \mu$ m; (e) Posterior end of male in lateral view: cloacal opening (cl), spicules (sp), gubernaculo (*) present, caudal wings (ca). Bar: $100 \mu \mu m$.

absent. Buccal capsule with three teeth; two lateral and one esophageal (Figure 1b). Esophagus divided into two parts: muscular and glandular, the latter being longer (Figure 1a). Nervous ring near the muscle-glandular transition (Figure 1a). Excretory pore hidden between cuticular projections, observed only under SEM (Figure 2b, 2c).

Males (Based on 10 specimens) (Figure 2d): body length $8 \mathrm{~mm}(6-10 \mathrm{~mm})$, maximum width at esophageal-intestinal junction 235 (178-307). Slightly elongated buccal capsule measuring $42(27-50) \times 34$ (28-36). Maximum length / width ratio of 1: 1 buccal capsule. Muscular portion of esophagus 356 (187-440) long and 37 (28-50) wide; glandular portion of esophagus $3 \mathrm{~mm}(2-3 \mathrm{~mm}$ ) long and 99 (85-112) wide. Muscular / glandular esophagus length ratio 8: 1. Length of entire esophagus and buccal capsule $37 \%$ of body length. Nerve-ring is located 232 (132-315) from the previous extremity. Two subventral rows of cutaneous plaques from 104 to 111 projections. Ventrally furrowed, coiled posterior end with two delicate lateral wings supported by three pairs of pre-cloacal pedunculated papillae and seven pairs of postcloacal papillae (six pedunculated pairs and one pair of tail tip sessile papillae) (Figures 1e, 2g). Unpaired ventral papilla is located slightly anterior to the upper cloacal lip. Two of the six pairs of postcloacal pedunculated papillae are medial to the others near the ventral sulcus. Cloacal opening surrounded by numerous rounded verruciform rectilinear projections. Prior to the caudal wings there are 7 to 8 semicircular, 

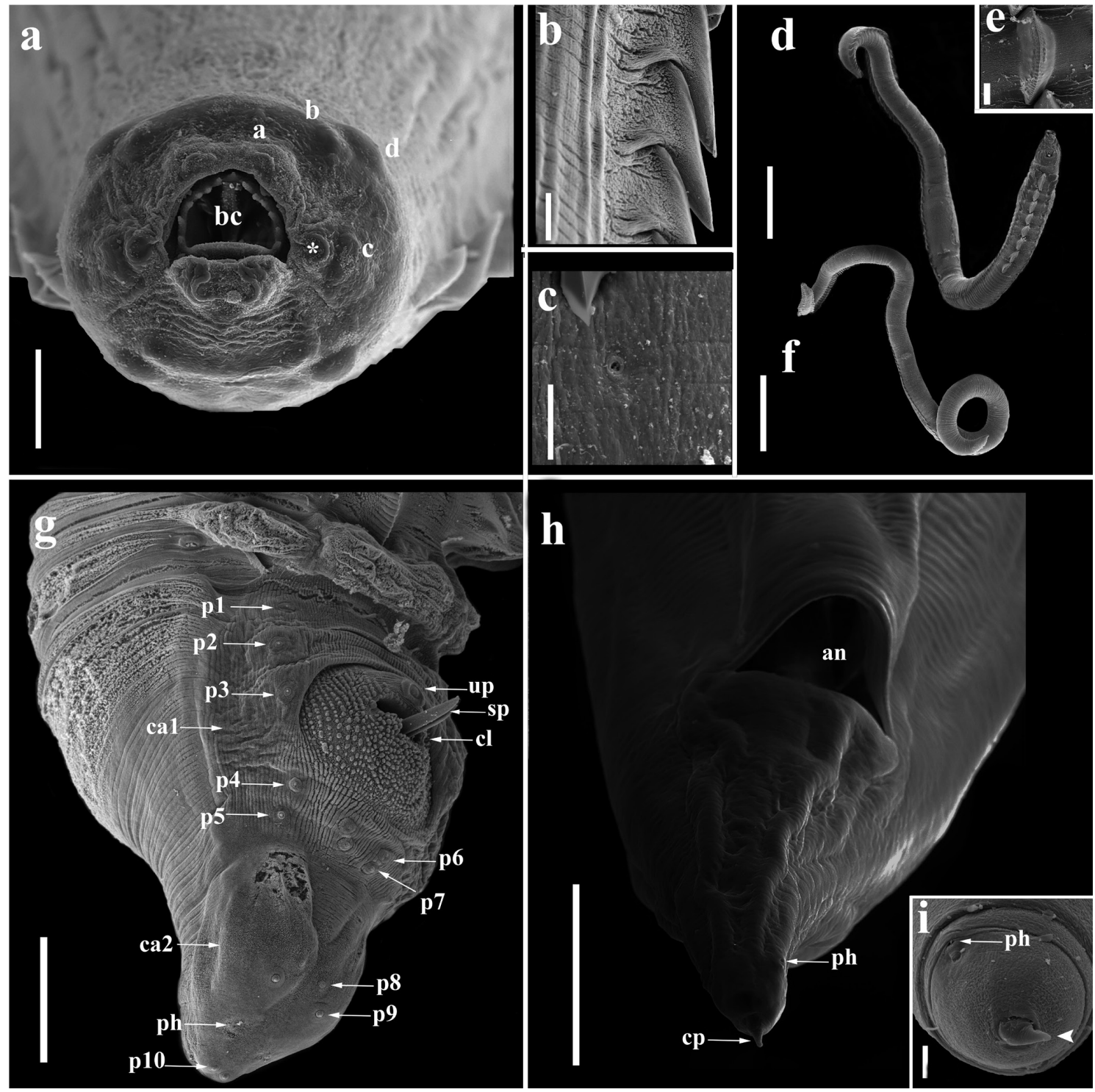

Figure 2. Scanning electron microscopy of Pterygodermatites (M.) affinis parasite of Cerdocyon thous in the state of Pará, Brazil. (a) Anterior end in apical view of a male showing: buccal capsule (bc), three circles of papillae: (a) an inner circle four papillae, with was a pair of amphids (*) between the ventral and dorsal labial papillae, (b) external circles with four papillae 1 ventral pair, 1 dorsal pair; (c) 1 lateral pair adjacent to amphids and (d) the outer circles showing four simple papillae. Bar: 20 um;

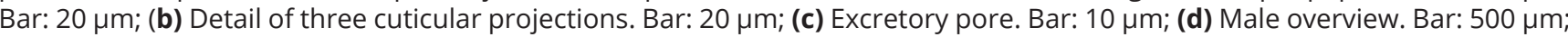
(e) Detail of a semicircular and striated projection of the male. Bar: 20 um; (f) Female overview. Bar: 1 mm; (g) Posterior end in lateral view of a male specimen highlighting 10 papillae (p1-p10), unpaired papillae (up) in the upper lip of cloacal (cl), spicules (sp), caudal wings (ca1 and ca2) present and divided in two portions, phasmids (ph) located between the papillae p9 and p10. Bar: $100 \mu \mathrm{m}$; (h) Female ventral posterior end: anal opening (an), phasmids (ph), cuticular projection (cp). Bar: 50 um; (i) Detail of the cuticular projection (arrowhead). Bar: $5 \mu \mathrm{m}$. Scale bars: A. $20 \mu \mathrm{m}$, B. $20 \mu \mathrm{m}$, C.10 $\mu \mathrm{m}$, D. $500 \mu \mathrm{m}, \mathrm{E} .20 \mu \mathrm{m}, \mathrm{F} .1 \mathrm{~mm}$, G. $100 \mu \mathrm{m}, \mathrm{H} .50 \mu \mathrm{m}$, I. $5 \mu \mathrm{m}$.

striated, plaque-like projections located between the ventricle-lateral skin lines (Figure 2e). Short, sharp spikes, subequal in size and shape; right spicule 203 (183-228) long and left spicule short 177 (143-190) long (Figure 1e). Well sclerotized gubernaculum present and spoon-shaped in the lateral view, measuring 69 (60-93) length and 15 (10-33) width. Tail length 321 (228-390).

Females (Based on 10 gravid specimens with immature eggs) (Figure. 2f): body length $14 \mathrm{~mm}(11-17 \mathrm{~mm}$ ), maximum width at esophageal-intestinal junction 283 (203-347). Oral capsule slightly longer than in males, measuring 52 (38-63) in length and 42 (37-52) in width. Maximum length/width ratio of 1: 1 buccal capsule. Muscular portion of esophagus 396 (274-557) long and 45 (32-63) wide; glandular portion of esophagus $3 \mathrm{~mm}(3-4 \mathrm{~mm})$ long and 113 (93-130) wide. Muscular/glandular esophagus length ratio 8: 1. Length of entire esophagus and buccal capsule 
$27 \%$ of body length respectively. Nerve-ring is located 249 (117-338) from the previous extremity. Two subventral rows of cuticular projections 103 to 150. Pre-equatorial vulva located $4 \mathrm{~mm}$ (3-5 mm) [48-61 cuticular projections] of anterior extremities, at about $28 \%$ of body length (Figure 1c). Amphidelphic, branched uterus containing eggs in various embryonic stages, which are 29 (18-38) long, 21 (15-26) wide. Tapered tail with anal opening 231 (183-407) from tail tip that has a thorn-like terminal projection, with a length of $5 \mathrm{~mm}(3-6 \mathrm{~mm}$ ) (Figures. 1d, 2h, i).

\section{Discussion}

The nematodes recovered from the small intestine of $C$. thous have characteristics similar to those of the Family Rictulariidae, genus Pterygodermatites and the subgenus Multipectines and morphologically identified the species $P$. (Multipectines) affinis. The Subgenus Multipectines is composed of three species: $P$. (Multipectines) cahirensis (Jägerskiöld, 1909), P. (Multipectines) affinis and P. (Multipectines) pluripectinata (Hoppe, Araujo de Lima, Tebaldi \& Nascimento, 2010) that differentiate in number and distribution of denticles, cuticular projections and length. Morphological and morphometric data of $P$. (Multipectines) affinis collected in C. thous of the municipality of Paragominas are compared to the morphometric data of $P$. (Multipectines) affinis and $P$. (Multipectines) pluripectinata harvested from different hosts in Brazil in Table 1.

Table 1: Comparison of morphometric characteristics of the specimes Pterygodermatites (Multipectines) affinis and species of the subgenus Multipectines from Brazil.

\begin{tabular}{|c|c|c|c|c|c|c|c|c|}
\hline \multirow{2}{*}{ Caracteres } & \multicolumn{8}{|c|}{ Pterygodermatites (Multipectines) affinis (Jägerskiöl, 1904) } \\
\hline & Male & Female & Male & Female & Male & Female & Male & Female \\
\hline $\begin{array}{c}\text { Hosts } \\
\text { Site of infection } \\
\text { Type locality } \\
\text { Bioma }\end{array}$ & \multicolumn{2}{|c|}{$\begin{array}{c}\text { Cerdocyon thous } \\
\text { Intestine } \\
\text { Pará, Brazil } \\
\text { Amazônia }\end{array}$} & \multicolumn{2}{|c|}{$\begin{array}{l}\text { Cerdocyon thous } \\
\text { Intestine } \\
\text { Minas Gerais, Brazil } \\
\text { Atlantic Florest }\end{array}$} & \multicolumn{2}{|c|}{$\begin{array}{l}\text { Canis aureus } \\
\text { Intestine } \\
\text { Paraíba, Brazil } \\
\text { Caatinga }\end{array}$} & \multicolumn{2}{|c|}{$\begin{array}{c}\text { L. gymnocercus } \\
\text { Intestine } \\
\text { Argentina } \\
\text { Pampa }\end{array}$} \\
\hline Length $(\mathrm{mm})^{\mathrm{a}}$ & $6-10(8)^{c}$ & $11-17(14)$ & 6.8 & 18.4 & 9.2 & 11.86 & $2-12(7.2)$ & $9-20(13.85)$ \\
\hline Width & $\begin{array}{l}178-307 \\
(235)\end{array}$ & $\begin{array}{l}203-347 \\
(283)\end{array}$ & $176-<$ & $(350.25)$ & 167 & 184 & $\begin{array}{c}150-315 \\
(243)\end{array}$ & $\begin{array}{c}165-475 \\
(328)\end{array}$ \\
\hline $\begin{array}{c}\text { Number of } \\
\text { cuticular plates }\end{array}$ & 104-111 & $103-150$ & $98-110$ & - & $102-114$ & $127-139$ & $\begin{array}{l}107-120 \\
(112)\end{array}$ & $\begin{array}{l}123-140 \\
(132)\end{array}$ \\
\hline $\begin{array}{c}\text { Buccal } \\
\text { capsule }^{L, b}\end{array}$ & $27-50(42)$ & $38-63(52)$ & \multicolumn{2}{|c|}{$25-62.5(34.88)$} & - & - & 25-39 (35) & $38-45(41)$ \\
\hline $\begin{array}{l}\text { Buccal } \\
\text { capsule }^{\mathrm{w}, \mathrm{b}}\end{array}$ & $28-36(34)$ & $37-52(42)$ & \multicolumn{2}{|c|}{$16-55(48.88)$} & - & - & $35-55(47.3)$ & $60-75(63)$ \\
\hline Nervous ring & $\begin{array}{c}132-315 \\
(232)\end{array}$ & $\begin{array}{c}117-338 \\
(249)\end{array}$ & - & - & - & - & 160 & $\begin{array}{l}220-400 \\
(310)\end{array}$ \\
\hline $\begin{array}{c}\text { Muscular } \\
\text { esophagus }{ }^{\mathrm{L}, \mathrm{b}}\end{array}$ & $\begin{array}{c}187-440 \\
(356)\end{array}$ & $\begin{array}{l}274-557 \\
(396)\end{array}$ & \multicolumn{2}{|c|}{$3.23^{d}$} & $2.9^{d}$ & $3.5^{\mathrm{d}}$ & $\begin{array}{c}0.009-1.46 \\
(1.14)^{\mathbf{e}}\end{array}$ & $\begin{array}{c}1.65-2.98 \\
(2.37)^{\mathrm{e}}\end{array}$ \\
\hline $\begin{array}{l}\text { Glandular } \\
\text { esophagus } \\
(\mathrm{mm})^{\mathrm{L}, \mathrm{b}}\end{array}$ & $2-3(3)$ & 3 & & & & & & \\
\hline Vulva (NCP),b & \multicolumn{2}{|c|}{$48-61$} & \multicolumn{2}{|c|}{$52-58$} & \multicolumn{2}{|c|}{$29-58$} & \multicolumn{2}{|c|}{$51-61$} \\
\hline Vulva (Position) & \multicolumn{2}{|c|}{ Prequatorial } & \multicolumn{2}{|c|}{ Prequatorial } & \multicolumn{2}{|c|}{ Prequatorial } & \multicolumn{2}{|c|}{ Prequatorial } \\
\hline Eggs ${ }^{L \times W, b}$ & \multicolumn{2}{|c|}{$18-38(29) 15-26(21)$} & \multicolumn{2}{|c|}{$14-16(15) \times 8-12(10.36)$} & \multicolumn{2}{|c|}{$24.9 \times 17$} & \multicolumn{2}{|c|}{$\begin{array}{c}35-38(36.25) \times 25-29 \\
(26.75)\end{array}$} \\
\hline
\end{tabular}

aMeasurements are given in micrometers unless otherwise noted; bAbbreviations: L: length, W: width, NCP: Number of cuticular projections from the extremity anterior to the vulva, pe: pedunculata, se: sessil, un: unpaired ventral papilla, ph: phasmids; ' ${ }^{c}$ Measurements are presented as the range (minimum and maximum values) followed by the mean in parentheses; ${ }^{\mathrm{d} T h e}$ author presents the total size of the esophagus (Muscular esophagus and glandular esophagus); eThe author presents of esophago morphometry in just one example (Male: Muscular esophagus $285 \mu \mathrm{m}$ and glandular esophagus $615 \mu \mathrm{m}$; Female: Muscular esophagus $353.75 \mu \mathrm{m}$ and glandular esophagus $2.13 \mathrm{~mm}$; fDistance from the anterior end to the vulva $2.20 \mathrm{~mm}(2.14-2.27 \mathrm{~mm})$; ${ }^{\text {DDistance }}$ from the anterior end to the vulva $5.25 \mathrm{~mm}(4.7-5.7 \mathrm{~mm})$. 
Table 1: Continued...

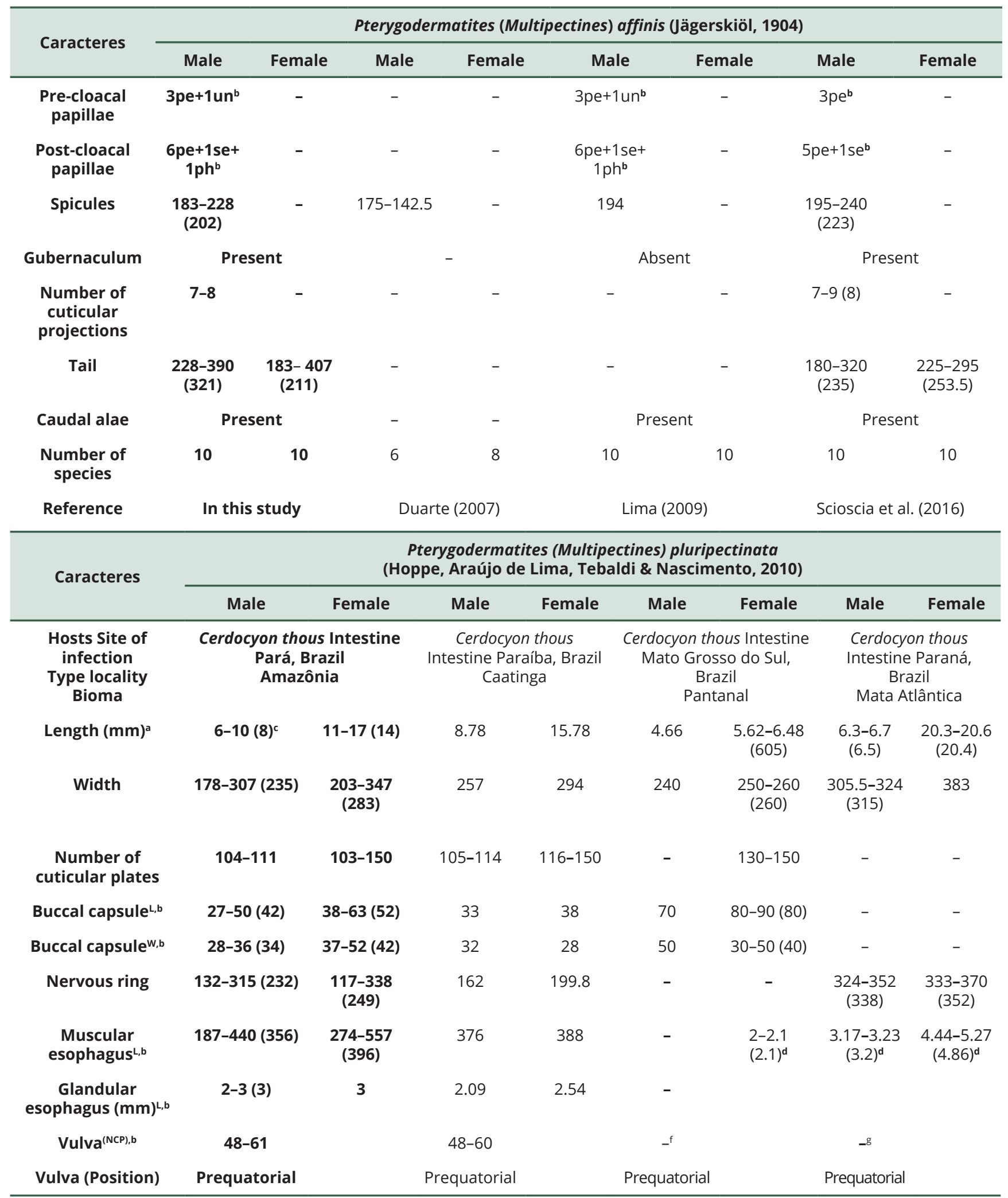

aMeasurements are given in micrometers unless otherwise noted; bAbbreviations: L: length, W: width, NCP: Number of cuticular projections from the extremity anterior to the vulva, pe: pedunculata, se: sessil, un: unpaired ventral papilla, ph: phasmids; cMeasurements are presented as the range (minimum and maximum values) followed by the mean in parentheses; ${ }^{\mathrm{d} T}$ The author presents the total size of the esophagus (Muscular esophagus and glandular esophagus); ' The author presents of esophago morphometry in just one example (Male: Muscular esophagus $285 \mu \mathrm{m}$ and glandular esophagus $615 \mu \mathrm{m}$; Female: Muscular esophagus $353.75 \mu \mathrm{m}$ and glandular esophagus $2.13 \mathrm{~mm}$; fDistance from the anterior end to the vulva $2.20 \mathrm{~mm}(2.14-2.27 \mathrm{~mm})$; gDistance from the anterior end to the vulva $5.25 \mathrm{~mm}(4.7-5.7 \mathrm{~mm})$ 
Table 1: Continued...

\begin{tabular}{|c|c|c|c|c|c|c|c|c|}
\hline \multirow{2}{*}{ Caracteres } & \multicolumn{8}{|c|}{$\begin{array}{l}\text { Pterygodermatites (Multipectines) pluripectinata } \\
\text { (Hoppe, Araújo de Lima, Tebaldi \& Nascimento, 2010) }\end{array}$} \\
\hline & Male & Female & Male & Female & Male & Female & Male & Female \\
\hline Eggs ${ }^{L \times W, b}$ & $\begin{array}{l}18-38(29) \times \\
15-26(21)\end{array}$ & & $38 \times 28.5$ & & - & & - & \\
\hline Pre-cloacal papillae & $3 p e+1 u^{b}$ & - & $3 p e^{b}$ & - & $3 p e^{b}$ & - & - & - \\
\hline $\begin{array}{l}\text { Post-cloacal } \\
\text { papillae }\end{array}$ & $6 p e+1 s e^{b}$ & - & $6 p e+1 s e^{b}$ & - & $6 p e+1 s e^{b}$ & - & - & - \\
\hline Spicules ${ }^{L, b}$ & $183-228(203)$ & - & 253 & - & 120 & - & $\begin{array}{c}213-241 \\
(227)\end{array}$ & \\
\hline Gubernaculum & Present & & Absent & & Absent & & - & \\
\hline $\begin{array}{l}\text { Number of } \\
\text { cuticular } \\
\text { projections }\end{array}$ & $7-8$ & - & $8-9$ & - & - & - & - & - \\
\hline Tail & $228-390(321)$ & $\begin{array}{l}183-407 \\
(211)\end{array}$ & - & 194 & - & $\begin{array}{l}140-200 \\
(170)\end{array}$ & - & - \\
\hline Caudal alae & Present & & Present & & Present & & - & \\
\hline Number of species & 10 & 10 & 10 & 10 & 1 & 2 & 2 & 2 \\
\hline Reference & In this study & & $\begin{array}{l}\text { Hoppe et al. } \\
\text { (2010) }\end{array}$ & & $\begin{array}{l}\text { Gomes et al. } \\
\text { (2015) }\end{array}$ & & $\begin{array}{l}\text { Moraes } \\
(2016)\end{array}$ & \\
\hline
\end{tabular}

a Measurements are given in micrometers unless otherwise noted; bAbbreviations: L: length, W: width, NCP: Number of cuticular projections from the extremity anterior to the vulva, pe: pedunculata, se: sessil, un: unpaired ventral papilla, ph: phasmids; 'Measurements are presented as the range (minimum and maximum values) followed by the mean in parentheses; ${ }^{\mathrm{d} T h e}$ author presents the total size of the esophagus (Muscular esophagus and glandular esophagus); eThe author presents of esophago morphometry in just one example (Male: Muscular esophagus $285 \mu \mathrm{m}$ and glandular esophagus $615 \mu \mathrm{m}$; Female: Muscular esophagus $353.75 \mu \mathrm{m}$ and glandular esophagus $2.13 \mathrm{~mm}$; 'Distance from the anterior end to the vulva $2.20 \mathrm{~mm}(2.14-2.27 \mathrm{~mm})$; ${ }^{8}$ Distance from the anterior end to the vulva $5.25 \mathrm{~mm}(4.7-5.7 \mathrm{~mm})$.

Quentin (1969), believed that the Multipectines Subgenus was restricted to Eurasia, howerer, new records were reported in different hosts and continents in South America Scioscia et al. (2016), describes the occurrence of P. (Multipectines) affinis in Argentina in Lycalopex gymnocercus (Fischer, 1814) and Duarte (2007); Lima et al. (2013) recorded the same species parasitizing $C$. thous in Brazil.

Pterygodermatites (Multipectines) affinis is believed to have been introduced in South America during the geographical expansion of $C$. thous, with fossil evidence from ancestral canids in North and Central America (Hoppe et al., 2010). Infection by this species probably occurs in C. thous due to the variety of intermediate invertebrate hosts that are part of their diet (Bianchi et al., 2014).

Of the published surveys of parasites of Brazilian mammals (Vicente et al., 1997; Vieira et al., 2008; Pinto et al., 2011), none shows the occurrence of $P$. (Multipectines) affinis in the Amazon biome, thus, this study presents the morphology and morphometry of $P$. (Multipectines) affinis recovered for the first time in a free-living mammal in the State of Pará, and in the Amazon biome.

For South America, Scioscia et al. (2016) describe the occurrence of $P$. (Multipectines) affinis in Argentina in L. gymnocercus (Carnivora: Canidae). In Brazilian territory Duarte (2007) describes the occurrence and morphology of the same species in Juiz de Fora, State of Minas Gerais (Atlantic Forest biome). For the Caatinga biome Lima et al. (2013) report the occurrence of $P$. (Multipectines) affinis parasitizing C. thous in the State of Paraíba and Hoppe et al. (2010) propose the species $P$. (Multipectines) pluripectinata as an intestinal parasite of the same host in the same biogeographic location. Gomes et al. (2015) expand the geographical distribution of P. (Multipectines) pluripectinata when reporting its occurrence in the State of Mato Grosso do Sul (Pantanal biome), and Moraes (2016) records the occurrence of $P$. (Multipectines) pluripectinata in the Iguaçu National Park, Paraná (Atlantic Forest biome), reporting a new distribution for the species in southern Brazil.

In this context, the study revealed similarities with the findings of Quentin (1969), confirming the identification of the species, in addition to adding important data for better morphological characterization such as: spoon-shaped 
gubernaculum (63-75 × 10-17) and distribution papillae (three pairs of pre-cloacal pedunculated papillae, seven pairs of postcloacal papillae and unpaired ventral papilla located slightly anterior to the upper cloacal lip), the spicules short, sharp, equal in size, with smooth or contracted sheaths.

Different from what was described by Scioscia et al. (2016), this work, the spicules do not have sclerotized rings around them, only the formation of folds with the contraction of the sheath, which we believe to be the sclerotized rings described by the referred authors.

Morphometrically, the intrauterine eggs of $P$. (Multipectines) affinis (18-38 $\times 15-26)$ in this study, presented a smaller size than that presented by Scioscia et al. (2016) when reporting parasitism by $P$. (Multipectines) affinis in L. gymnocercus in Argentina (see 35-38 × 25-29). In Brazil, Duarte (2007) and Lima (2009) describe the morphometry of $P$. (Multipectines) affinis eggs at different stages of development measured $15 \times 10.36$ and $24.9 \times 17$ respectively, which is different from the size observed in this work. In this study, we did not present a morphological characterization of the eggs, as we believe that throughout embryogenesis, characteristics such as size, color and thickness of the shell can undergo important changes, thus modifying a possible real diagnosis based on the characteristics of the eggs, although in other research the authors have only performed coprological exams to characterize the diversity of parasites in C. thous (Brandão et al., 2009).

Although studies of nematode egg morphology and morphometry are important for diagnosing diseases in endangered wild animal species, the identification of eggs does not provide a good means of diagnosis for helminth taxonomy, since some of them produce similar eggs among itself, and identification at a specific level is very difficult (Brandão, 2007).

\section{Conclusion}

This work, in addition to contributing morphological data and morphometry to aid in the identification of $P$. (Multipectines) affinis, also presents the occurrence of these nematode in C. thous in the Amazon biome, contributing to the expansion of the known geographic distribution of the parasite and knowledge of the helminthological fauna of the host species, which aids in redefining parasite boundaries.

\section{Acknowledgements}

The authors are grateful to the following the Universidade Federal Rural da Amazônia, Ricardo Luis Sousa Santana, Lityane Gabriela da Silva Moreira and Simone Marques da Silva for assistance during parasite harvesting. This study is part of the master dissertation of the first author from the Programa de Pós-Graduação em Biologia de Agentes Infecciosos e Parasitários - Universidade Federal do Pará. This study was financed in part by the Conselho Nacional de Desenvolvimento Científico e Tecnológico - Brasil (CNPq), Ministério da Educação do Brasil. Raul Henrique da Silva Pinheiro was supported by a research fellowship from the "Universidade Federal do Oeste do Pará - CAPES-BRASIL) - Finance Code 001"

\section{References}

Anderson RC, Chabaud AG, Willmott S. Keys to the nematode parasites of vertebrates: archival volume. Cabi; 2009. http://dx.doi. org/10.1079/9781845935726.0000.

Berta A. Cerdocyon thous. Mamm Species 1982; 186(186): 1-4. http://dx.doi.org/10.2307/3503974.

Bianchi RC, Campos RC, Xavier-Filho NL, Olifiers N, Gompper ME, Mourão G. Intraspecific, interspecific, and seasonal differences in the diet of three mid-sized carnivores in a large neotropical wetland. Acta Theriol (Warsz) 2014; 59(1): 13-23. http://dx.doi. org/10.1007/s13364-013-0137-x.

Brandão ML, Chame M, Cordeiro JLP, Chaves SAM. Diversidade de helmintos intestinais em mamíferos silvestres e domésticos na Caatinga do Parque Nacional Serra da Capivara, Sudeste do Piauí, Brasil. Rev Bras Parasitol Vet 2009;18(Suppl 1): 19-28. http:// dx.doi.org/10.4322/rbpv.018e1004. PMid:20040186.

Brandão ML. Helmintos de Mamíferos da Região do Parque Nacional Serra da Capivara, Sudeste do Piauí: diversidade e influências antrópicas [Dissertação]. Rio de Janeiro: Fundação Oswaldo Cruz; 2007.

Bush AO, Lafferty KD, Lotz JM, Shostak AW. Parasitology meets ecology on its own terms: margolis et al. revisited. J Parasitol 1997; 83(4): 575-583. http://dx.doi.org/10.2307/3284227. PMid:9267395. 
Duarte FH. Helmintofauna em Cerdocyon thous Linnaeus, 1766 (Carnivora, Canidae) na região de Juiz de Fora, Minas Gerais [Dissertação]. Minas Gerais: Universidade Federal de Juiz De Fora; 2007.

Gomes AP, Olifiers N, Santos MM, Simões RO, Maldonado A Jr. New records of three species of nematodes in Cerdocyon thous from the Brazilian Pantanal wetlands. Rev Bras Parasitol Vet 2015; 24(3): 324-330. http://dx.doi.org/10.1590/S1984-29612015061. PMid:26444063.

Hoppe EGL, Lima RCA, Tebaldi JH, Nascimento AA. Pterygodermatites (Multipectines) pluripectinata n. sp. (Spirurida: Rictulariidae), a nematode parasite of the crab-eating fox Cerdocyon thous (Linnaeus, 1766) from Caatinga shrubland, Brazil. J Helminthol 2010; 84(3): 312-316. http://dx.doi.org/10.1017/S0022149X0999071X. PMid:20056009.

Lima RC, Hoppe EGL, Tebaldi JH, Cruz BC, Gomes AAB, Nascimento AA. Gastrintestinal helminths of Cerdocyon thous (Linnaeus, 1766 - Smith, 1839) from the caatinga area of the Paraíba State, Brazil. Semina: Ciênc Agrár 2013; 34(6): 2879-2888. http://dx.doi. org/10.5433/1679-0359.2013v34n6p2879.

Lima RCA. Helmintos gastrointestinais de Cerdocyon thous (Linnaeus, 1766) Smith, 1839 provenientes da área de caatinga do Estado da Paraíba, Brasil [Dissertação]. São Paulo: Universidade Estadual de São Paulo; 2009.

Moraes MFD. Estudos parasitológicos em cães domésticos errantes e carnívoros selvagens generalistas no Parque Nacional do lguaçu, Foz do Iguaçu [Dissertação]. Jaboticabal: Universidade Estadual Paulista; 2016.

Pinheiro RHS, Chaves IBPC, Rodrigues RAR, Branco É; Lima AR, Giese EG. Nematode capilaridae in the tongue of Cerdocyon thous of free life in Brazil. Rev Bras Parasitol Vet 2018; 27(4): 531-544. https://doi.org/10.1590/S1984-296120180078

Pinto RM, Knoff M, Gomes DC, Noronha D. Nematodes from mammals in Brazil: An updating. Neotrop Helminthol 2011; 5(2): 139-183.

Prada CDS. Atropelamento de vertebrados silvestres em uma região fragmentada do nordeste do Estado de São Paulo: quantificação do impacto e análise de fatores envolvidos [Dissertação]. São Paulo: Universidade Federal de São Carlos; 2004.

Quentin JC. Essai de classificassion des Nématodes Rictulaires. Mem Mus Natn Hist Nat 1969; 54(1): 57-115.

Scioscia NP, Beldomenico PM, Denegri GM. New host and distribution expansion for Pterygodermatites (Multipectines) affinis. Helminthologia 2016; 53(1): 81-86. http://dx.doi.org/10.1515/helmin-2015-0076.

Simões MB. Pterygodermatites (Nematoda: Rictulariidae): revisão de literatura e identificação de espécies em quirópteros da mata atlântica, sudeste brasileiro [Dissertação]. Vitória: Universidade Federal do Espírito Santo, 2016.

Vicente JJ, Rodrigues HO, Gomes DC, Pinto RM. Nematóides do Brasil. Parte V: Nematóides de mamíferos. Rev Bras Zool 1997; 14(Suppl 1): 1-452. http://dx.doi.org/10.1590/S0101-81751997000500001.

Vieira FM, Luque JL, Muniz-Pereira LC. Checklist of helminth parasites in wild carnivore mammals from Brazil. Zootaxa 2008; 1721(1): 1-23. http://dx.doi.org/10.11646/zootaxa.1721.1.1. 